\title{
Spectrum of rare splenic lesions
}

\author{
Sushma Nigudgi ${ }^{1}$, Sneha Sheelwanth ${ }^{2, *}$, Anita. A.M³, Anuradha Patil ${ }^{4}$, Sainath .K Andola ${ }^{5}$ \\ ${ }^{\mathbf{1}}$ Assistant Professor, ${ }^{2}$ Resident, ${ }^{\mathbf{3}}$ Associate Professor, ${ }^{4}$ Professor and HOD, ${ }^{5}$ Professor and Director, Dept. of Pathology, M.R. \\ Medical College, Kalaburagi, Karnataka, India
}

*Corresponding Author:

Email: sbba7290@gmail.com

\begin{abstract}
Introduction: The human spleen is the largest component of the reticuloendothelial system, having unique anatomic and functional importance. Spleen has been considered as mysterious organ with World population incidence of focal splenic lesions ranging from 0.103 to $0.20 \%$.

Aims and Objective: The aim of the present study was to study the pathological spectrum of rare lesions of spleen.

Materials and Methods: The present study was conducted in the department of Pathology in a tertiary care centre, over a period of three years from Aug 2014 to July 2017.

Results: Total 10 rare cases of splenic lesions were studied. Out of which eight were splenectomies and two were from fetal autopsies. Primary lesions were 9 and secondary lesion was 1 . We found one case each of hemangiomatosis of spleen, small B cell lymphoma of spleen, Sickling of spleen, hydatid cyst of spleen, traumatic spleen avulsion, metastasis to spleen from lung and two case were of asplenia with right isomerism and situsambigus and two cases were of extra lymphatic filariasis of spleen.

Conclusion: Morphological changes in splenic lesions are less discussed due to fewer number of splenectomy cases. We hereby analyzed rare splenic lesions which has contributed to the knowledge of splenic pathology.
\end{abstract}

Keywords: Pathological spectrum, Splenic lesions, Splenectomy.

\section{Introduction}

The human spleen is the largest component of the reticuloendothelial system, having unique anatomic and functional importance, has been considered as mysterious organ and as forgotten organ. ${ }^{1,2}$ Splenic lesions are rare, posing a challenge for both interpreting and referring physicians in determining the need for and type of further evaluation, most of them are detected incidentally. ${ }^{2}$ World population incidence of focal splenic lesions ranges from 0.103 to $0.20 \% .^{3}$ Malignant lesions rarely occur in spleen having the ratio of benign versus malignant focal splenic lesions of 1:3. Solitary lesions are often benign, while multiple and fast growing lesions are more frequently malignant lesions like lymphoma, metastasis. ${ }^{3}$ While evaluating splenic lesions, it is important to take into account clinical factors, most importantly pain attributable to the spleen, signs and symptoms of infection, immune status, history of known malignancy, associated findings on imaging of the chest, abdomen or pelvis and a history of abdominal trauma, either recent or remote. ${ }^{2}$ The recent introduction of contrast-enhanced ultrasound (CEUS), an ionizing radiation-free investigation is helpful in imaging of splenic pathologies. ${ }^{4}$

The main objective of this study was to evaluate the spectrum of rare splenic lesions. We hereby present surgical pathological spectrum of unusual lesions of spleen.

\section{Materials and Methods}

We examined 10 rare lesions of spleen studied in the department of Pathology in a tertiary care centre, over a period of three years from Aug 2014 to July
2017. Out of 10, eight were splenectomy cases and two were fetal autopsies cases. Out of which primary cases were nine and one secondary case. Detail clinical history regarding age, presenting complaints, clinical diagnosis was taken. Thorough morphological examination of the gross specimen of spleen was carried out. Consent was taken from ethical committee of the institute prior to commencement of study.

\section{Result}

Out of 10 rare case series of splenic lesions, eight were splenectomy cases and two were from fetal autopsies. Of eight splenectomy, 6 cases were male and 2 female cases with age ranged between 10-55yrs. Of two spleen specimen from fetal autopsies, gestational age was 32 and 38 weeks.

Case 1: 50 years male, who presented with distension of abdomen, with gross showing enlarge intact spleen measuring $18 \times 7 \times 8$ with thickened areas of fibrosis and septa on cut section. [Fig. 1 -A]. Microscopy showed presence of cystically dilated spaces which are lined by endothelial cells filled with RBC. This was a case of hemangiomatosis of spleen (Fig. 1 -B)

Case 2: 55 years old male presented with generalised weakness, fever and Pain abdomen since 3 months with pancytopenia and splenomegaly. Grossly Splenomegaly with haemorrhage was seen [Fig. 2-A] with microscopy which showed Monotonous population of small lymphocytes and mitotic activity. This was a case of Small B cell lymphoma of Spleen. (Fig. 2-B)

Case 3: 51 years old male who died due to organophosphorus poisoning, where Spleen showed marked congestion with disseminated intravascular 
sickling. This was a case of Sickling of spleen (incidental finding) (Fig. 3)

Case 4 and 5: These were fetal autopsy cases which showed asplenia associated with other abnormalities. One of the cases showed dextrocardia, trilobed lung with central located liver with Stomach which was centrally and posteriorly located. Heart which showed presence of mitral stenosis, dilated right ventricles and hypoplastic heart. This was a case of Right Isomerism with asplenia. (Fig. 4). Other case showed right Lung two lobes, left lung three lobes, liver and stomach were centrally located with absent spleen. This was a case of Asplenia with Situsambigus. (Fig. 5)

Case 6: Showed grossly a Large hydatid spleen [Fig. 6A] with microscopy which showed the presence of Cyst wall composed of acellular laminated external layers with daughter cyst and hooklets. [Fig. 6-B, C] This was a case of Hydatid cyst of spleen.

Case 7: Showed lacerated spleen grossly, [Fig.7-A], areas of haemorrhage in Splenic tissue was seen microscopically [Fig. 7- B]. This was a case of Traumatic splenic avulsion

Case 8 and 9: One case presented with fever, pain abdomen, Cervical and axillary lymphadenopathy. Ultrasonography revealed splenomegaly and multiple abscess and other case presented with with pain abdomen, eosinophilia with splenomegaly. Both cases showed splenomegaly with two small nodules [Fig. 8 A] and microscopy showed Splenic nodules with eosinophil's, macrophage and Foreign body giant Cells. Macrophages surrounded by filariasis parasite [Fig. 8B, C]. They were the cases of Extra Lymphatic Filariasis of spleen.

Case 10: Patient presented with pain abdomen, Splenomegaly with engorged vein present. Ultrasonography showed the presence of splenic cyst. [Fig. 9 -A]. Microscopically showed the presence of splenic tumor cell having glandular pattern of poorly differentiated adenocarcinoma. This was a case of Metastasis to spleen from lung. (Fig. 9- B, C)
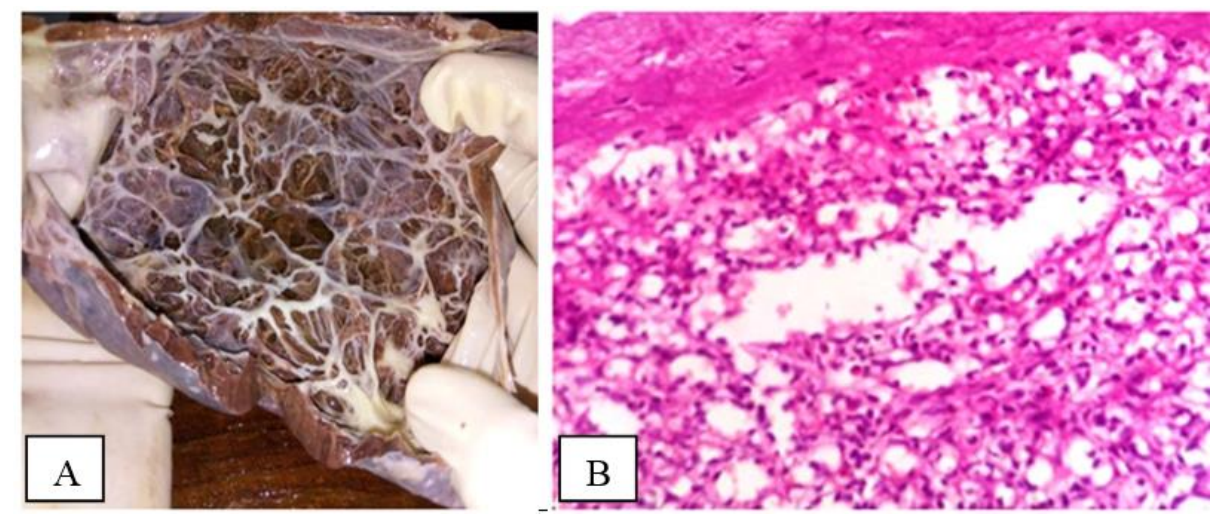

Fig. 1A: Cut surface of spleen showing thickened areas of fibrosis and septa; (B): Microscopy showing cystic dilated spaces lined by endothelial cells filled with RBC in 100X
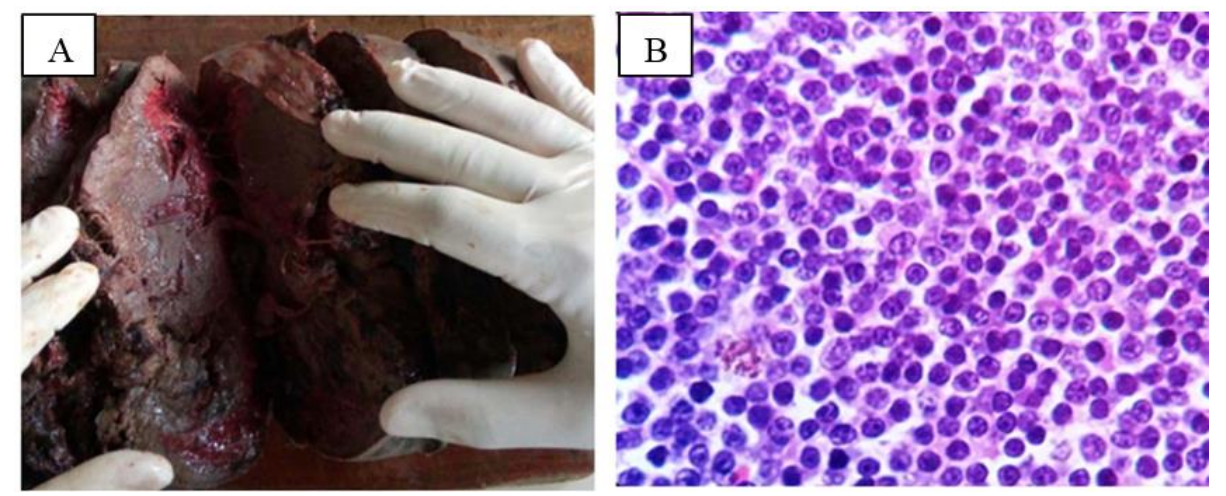

Fig. 2 A: Grossly-Splenomegaly with haemorrhage; (B): Monotonous population of small lymphocytes showing scant mitotic activity $100 \mathrm{x}$ 


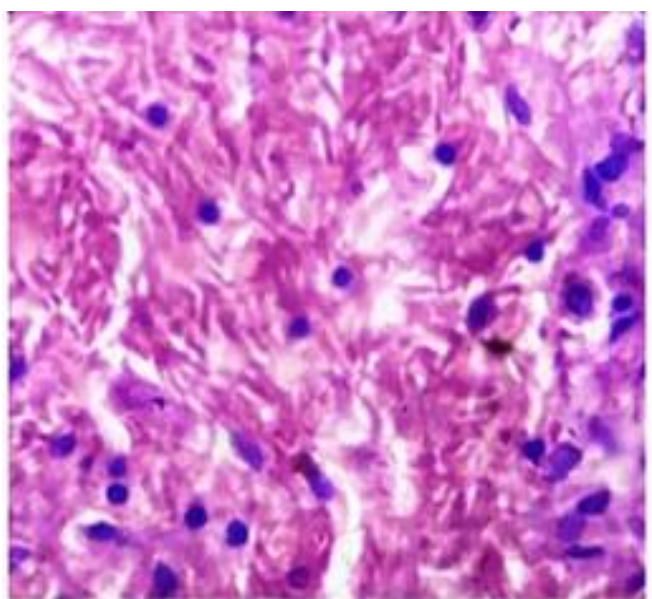

Fig. 3: Spleen show marked congestion with disseminated intravascular sickling $100 \mathrm{X}$

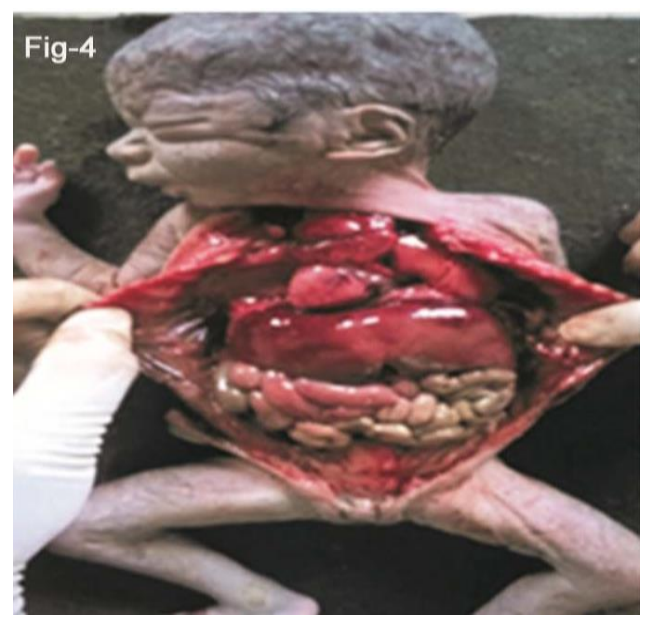

Fig. 4: Right isomerism with asplenia
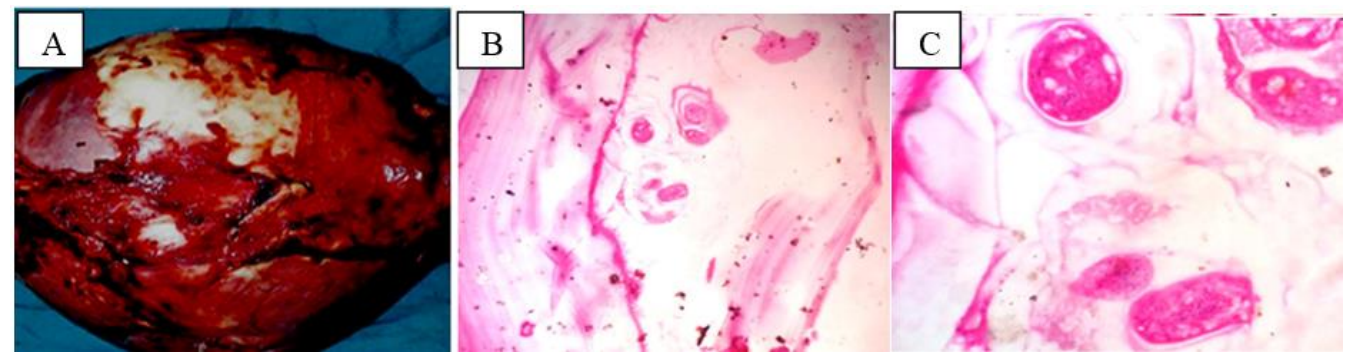

Fig. 6A: Grossly-Large hydatid spleen; (B, C): Cyst wall composed of acellular laminated external layers. Showing daughter cyst and hooklets
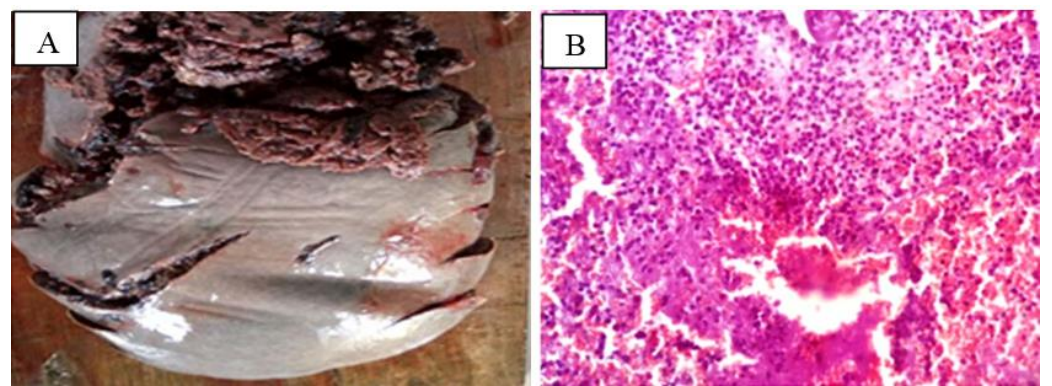

Fig. 7A: Gross: Lacerated spleen specimen; (B): Areas of haemorrhage in splenic tissue 

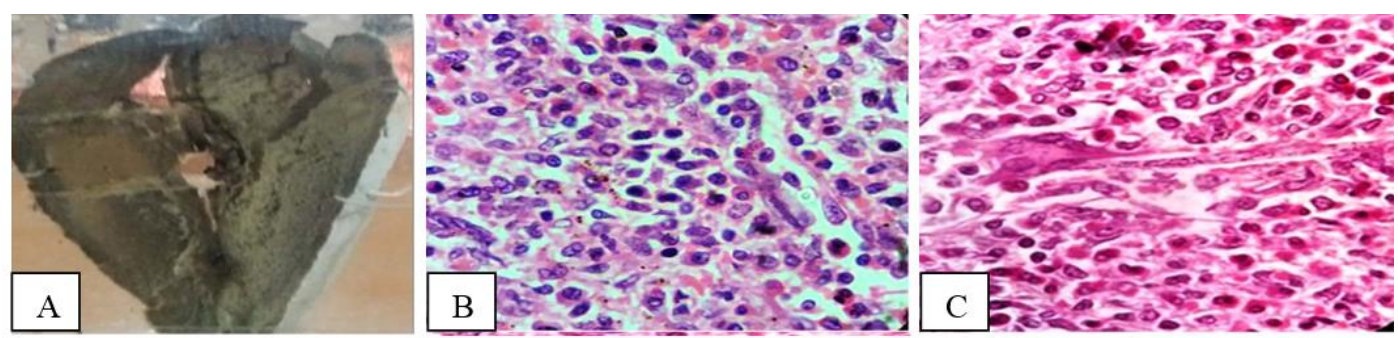

Fig. 8 A: Gross Mounted specimen of splenomegaly with two small nodules; (B): Extra lymphatic filariasis of spleen; (C): Extra lymphatic filariasis
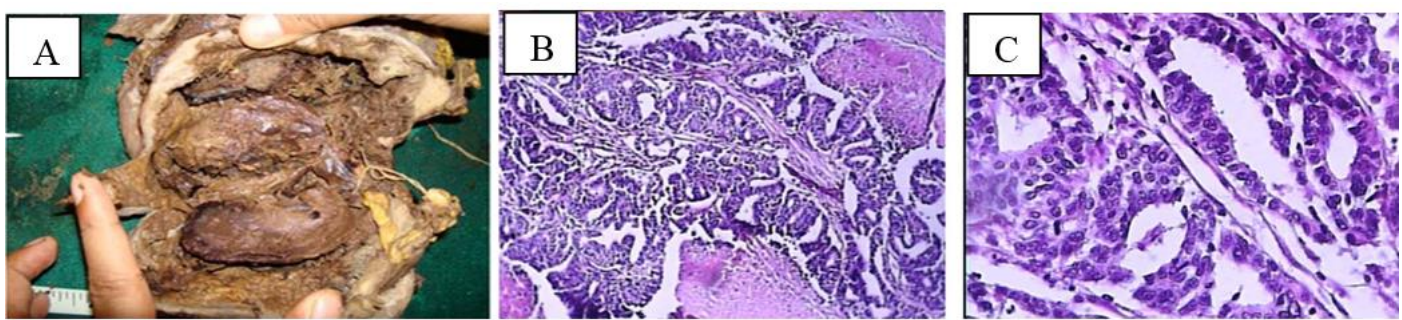

Fig. 9A: Grossly-spenomegaly present cut section shows irregular nodular surface containing cyst measuring $15 \times 10 \times 6 \mathrm{~cm} ;(\mathrm{B}, \mathrm{C})$ : Splenic tumor cell shows glandular pattern of poorly differentiated adenocarcinoma

Table 1: Showing ten cases of splenic lesions

\begin{tabular}{|c|c|c|c|c|c|}
\hline Case no. & Age & Sex & Clinical presentation & Clinical diagnosis & $\begin{array}{c}\text { Histopathological } \\
\text { diagnosis }\end{array}$ \\
\hline Case 1 & 14 years & Male & Distension of abdomen & Hemangioma & $\begin{array}{c}\text { Hemangiomatosis of } \\
\text { spleen }\end{array}$ \\
\hline Case 2 & 55 years & Male & $\begin{array}{l}\text { Generalised weakness, fever, } \\
\text { pain abdomen with } \\
\text { splenomegaly }\end{array}$ & Hypersplenism & $\begin{array}{l}\text { Splenic B cell } \\
\text { lymphoma }\end{array}$ \\
\hline Case 3 & 51 years & Male & Organophosphorus poisoning & $\begin{array}{l}\text { Died due to } \\
\text { Organophosphorus } \\
\text { poisoning }\end{array}$ & $\begin{array}{l}\text { Sickling of spleen } \\
\text { (incidental finding) }\end{array}$ \\
\hline Case 4 & 38 weeks fetus & Male & - & Fetal autopsy & $\begin{array}{l}\text { Asplenia with right } \\
\text { isomerism }\end{array}$ \\
\hline Case 5 & 32 weeks fetus & Female & - & Fetal autopsy & $\begin{array}{c}\text { Asplenia with } \\
\text { situsambigus }\end{array}$ \\
\hline Case 6 & 22 years & Male & Pain abdomen & Pain abdomen & Hydatid cyst \\
\hline Case 7 & 22 years & Male & Pain abdomen & $\begin{array}{c}\text { Blunt injury } \\
\text { abdomen }\end{array}$ & $\begin{array}{c}\text { Traumatic splenic } \\
\text { avulsion by mild injury }\end{array}$ \\
\hline Case 8 & 10 years & Male & $\begin{array}{c}\text { Fever, pain abdomen, } \\
\text { cervical and axillary } \\
\text { lymphadenopathy }\end{array}$ & Splenomegaly & Filariasis of spleen \\
\hline Case 9 & 15 years & Female & $\begin{array}{c}\text { Pain abdomen, eosinophilia } \\
\text { with splenomegaly }\end{array}$ & Splenomegaly & Filariasis of spleen \\
\hline Case 10 & 40 years & Female & $\begin{array}{l}\text { Pain abdomen, splenomegaly } \\
\text { with engorged veins }\end{array}$ & Splenic cyst & $\begin{array}{l}\text { Metastasis to spleen } \\
\text { from lung }\end{array}$ \\
\hline
\end{tabular}

\section{Discussion}

Splenic lesions presents as a diagnostic challenge to clinicians as they can involve both red and white pulp and can be neoplastic and nonneoplastic. ${ }^{3}$ William Osler in 1908 noted conditions associated with splenomegaly "nearly all diseases of the spleen are of a secondary nature. ${ }^{3}$ Most common benign lesion comprise of cyst, of which congenital cysts, posttraumatic cysts and dermoid cysts account for $64.7 \%$, $11.6 \%$, and $5.8 \%$ respectively. ${ }^{3}$ World population incidence of focal splenic lesions ranges from 0.103 to
$0.20 \%$; of these lesions true cysts account for $21.35 \%$, angiomas $14.56 \%$, calcification and infarctions $9.7 \%$, pseudocysts, also referred to as false cysts, $8.73 \%$, lymphomas and abscesses $7.76 \%$, and metastases $4.85 \% .^{3}$ Study conducted by Paluska et al in patients undergoing computed tomography (CT) scans for abdominal pain/trauma, found incidental splenic lesions in $1 \%$ of patients, which were mostly considered clinically benign. ${ }^{2}$ 
We found 10 cases of rare splenic lesions of which Diffuse hemangiomatosis of the spleen is a rare benign vascular condition accounting for $02 \%$ to $0.16 \%$ of total visceral organs hemangioma. ${ }^{5}$ Splenic small B cell lymphoma diagnosed $9 \%$ to $10 \%$ on splenctomy specimen and $10 \%$ to $30 \%$ of patients having splenic involvement at presentation. ${ }^{6,2}$ One of the cases was of acute splenic sequestration whose overall incidence is $4.0 \%$ cases of total sickle cell anemia cases. ${ }^{7} \mathrm{Rt}$ isomerism with Asplenia which is present in two cases of fetal autopsies has an incidence of 1 in to 10000 birth. ${ }^{8}$ Spleen is third most common organ involved in the Hydatid disease with World-wide incidence of 0.5 $4 \% .^{9}$ Mild trivial injury like fall can cause avulsion of spleen having incidence of $5 \%$ to $7 \%$ of all splenic injury. ${ }^{10}$ Splenic involvement in extra lymphatic filariasis extremely rare condition around $0.5 \%$ to $1.5 \% .^{11}$ Splenic metastasis from primary lung tumor is rare with an average incidence of metastasis to spleen at autopsy and at splenectomy was $0.6 \%$ and $1.1 \%$ respectively. ${ }^{12}$

\section{Conclusion}

Morphological changes in splenic lesions are less discussed due to fewer number of splenectomy cases. We here analyzed rare splenic lesions which has contributed to the knowledge of splenic pathology.

\section{References}

1. Giovagnoni A, Giorgi $\mathrm{C}$ and Goteri G. Tumours of the spleen. Cancer Imaging. 2005;5:73-77.

2. Thut D, Smolinski S, Morrow M, McCarthy S, Alsina J, Kreychman A. A diagnostic approach to splenic lesions. Appliedradiology. 2017:7-22.

3. Caremani M, Occhini U, Caremani A, Tacconi D, Lapini L, Accorsi A, Mazzarelli C. Focal splenic lesions: US findings. J Ultrasound. 2013;16:65-74.
4. Zavariz JD, Konstantatou E, Deganello A, Bosanac D, Huang DY, Sellars ME, Sidhu PS. Common and uncommon features of focal splenic lesions on contrastenhanced ultrasound: a pictorial review. Radiol Bras. 2017;50(6):395-404.

5. Eliyatkin N, Kececi S D, SezginA, Postaci H, Tekeli T, Denecli A G. Diffuse hemangiomatosis of the spleen case report: Aegean Pathology Journal. 2006;3:14-17.

6. Santos TS, Tavares RS, Farias D. Splenic marginal zone lymphoma: a literature review of diagnostic and therapeutic challenges: Rev Bras Hematol Hemoter. 2017;39(2):146-154.

7. Gamit B, Patel A, Shah P, Padsala S. Autopsy findings and pattern of mortality in undiagnosed sickle cell disease patients: Int J Community Med Public Health. 2016;3(5):1094-1100.

8. Jacobs JP, Anderson RH, Weinberg PM, et al. The nomenclature, definition and classification of cardiac structures in the setting of heterotaxy. Cardiol Young. 2007;17(Suppl 2):1-28.

9. Khalid Raseed et al. Hydatid cyst of spleen: A diagnostic challenge. N Am Med Sci. 2013;5(1):10-20.

10. 10.Costa G, Tierno SM, Tomassini F, Venturini L, Frezza B, Cancrini G, et al. The epidemiology and clinical evaluation of abdominal trauma: an analysis of a multidisciplinary trauma registry. Ann Ital Chir. 2010;81:95-102.

11. Dreyer G, Dreyer P and Piessens W.F. Extralymphatic disease due to bancroftianfilariasis: Braz J Med Biol Res. 1999;32(12).

12. Lam K.Y, Tang V. Metastatic Tumors to the Spleen. A 25-Year Clinicopathologic Study: Arch Pathol Lab Med. 2000;124:526-530.

How to cite this article: Nigudgi $S$, Sheelwanth S, Anita AM, Patil A, Andola SK. Spectrum of rare splenic lesions. J Diagn Pathol Oncol. 2018;4(3):223-227. 